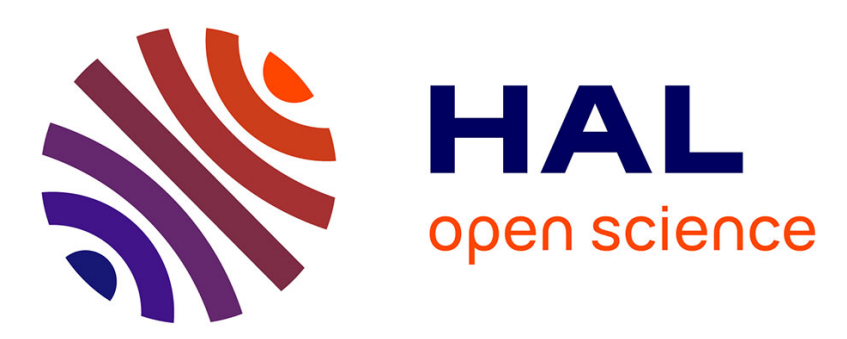

\title{
No limit?: the multiphasic uptake of silicic acid by benthic diatoms
}

Aude Leynaert, Sorcha Ni Longphuirt, Pascal Claquin, Laurent Chauvaud, Olivier Ragueneau

\section{- To cite this version:}

Aude Leynaert, Sorcha Ni Longphuirt, Pascal Claquin, Laurent Chauvaud, Olivier Ragueneau. No limit?: the multiphasic uptake of silicic acid by benthic diatoms. Limnology and Oceanography, 2009, 54 (2), pp.571-576. hal-00451210

\section{HAL Id: hal-00451210 https://hal.univ-brest.fr/hal-00451210}

Submitted on 28 Jan 2010

HAL is a multi-disciplinary open access archive for the deposit and dissemination of scientific research documents, whether they are published or not. The documents may come from teaching and research institutions in France or abroad, or from public or private research centers.
L'archive ouverte pluridisciplinaire HAL, est destinée au dépôt et à la diffusion de documents scientifiques de niveau recherche, publiés ou non, émanant des établissements d'enseignement et de recherche français ou étrangers, des laboratoires publics ou privés. 


\section{No limit? : the multiphasic uptake of silicic acid by benthic}

\section{diatoms}

Aude Leynaert, ${ }^{1, *}$ Sorcha Ni Longphuirt, ${ }^{1}$ Pascal Claquin, ${ }^{2}$ Laurent Chauvaud, ${ }^{1}$ Olivier Ragueneau ${ }^{l}$.

Submitted as a note to Limnology and Oceanography

${ }^{1}$ Laboratoire des Sciences de 1'Environnement Marin, UMR 6539, Institut Universitaire Européen de la Mer, Technopôle Brest-Iroise, 29280 Plouzané, France.

${ }^{2}$ Laboratoire de Biologie et Biotechnologies Marines, UMR100 M IFREMER PE2M, Université de Caen Basse-Normandie, 14032 Caen cedex, France.

Running head: Multiphasic uptake of silicic acid

* Corresponding author email: aude.leynaert@univ-brest.fr 


\section{Acknowledgments}

This work is part of the "Natural and Anthropogenic Modifications of the Si Cycle Along the Land-Ocean Continuum: Worldwide Ecological, Biogeochemical and Socioeconomical Consequences" (Si-WEBS) Research Training Network, funded by the European Union (HPRN-CT-2002-00218) and the national program "ECosphère COntinentale : processus et modélisation" (ECCO). We thank Erwan Amice and Robert Marc for their technical assistance during sampling, Beatriz Beker for cell identification and numeration and Annick Masson for elemental analyses. We are grateful for the very helpful comments of the anonymous reviewers. Thanks are also due to Christina De La Rocha for her careful reading and fruitful annotations on the manuscript. 


\begin{abstract}
Silicic acid uptake kinetics for a field population of benthic diatoms were examined using a radioisotope tracer over a concentration range of $0-300 \mu \mathrm{mol} \mathrm{L}^{-1}$. The microphytobenthos half saturation constant $\left(54 \mu \mathrm{mol} \mathrm{L}^{-1}\right)$ and specific uptake rates $\left(0.096 \mathrm{~h}^{-1}\right)$ for silicic acid were well above those usually found in the pelagic environment. Silicic acid kinetics were hyperbolic only at low concentrations $\left(<60 \mu \mathrm{mol} \mathrm{L} \mathrm{L}^{-1}\right)$. At higher concentrations, a second mechanism that did not suggest saturation was activated. Many benthic diatoms are motile and migrate vertically in the upper few centimeters of sediment where there are strong gradients of nutrient concentrations. The multiphasic uptake may allow them to take maximum advantage of the high silicic acid concentrations found at depth.
\end{abstract}




\section{Introduction}

Benthic diatoms constitute the major taxa of the microphytobenthic biomass in most marine sedimentary environments (Cahoon 1999). They colonize intertidal and subtidal areas in all latitudes and can contribute significantly to primary production in coastal zones (Mac Intyre et al. 1996; Cahoon 1999). By forming dense microbial mats at the sediment-water interface, benthic diatoms also alter the properties of sediments (Ziervogel and Forster 2006), and play a key role in controlling nutrient fluxes across the sediment-water interface (Sigmon and Cahoon 1997) with important implications for the functioning of the pelagic ecosystem. For example, due to their direct uptake of dissolved silica (DSi) at the sediment-water interface, benthic diatoms can greatly influence DSi released to the water column (Sigmon and Cahoon 1997; Srithongouthai et al. 2003) and play a important role in the dominance of specific pelagic phytoplankton groups (Conley 1993). Indeed, when DSi becomes limiting, a shift from diatoms to non-siliceous algae can occur, which may increase the likelihood of harmful algal blooms and have dramatic consequences for the transfer of carbon to higher trophic levels.

To our knowledge, the dynamic of DSi uptake by these benthic microalgal communities remains unquantified. The purpose of this study was thus to examine the silicic acid uptake kinetics for a field population of benthic diatoms.

\section{Methods}

\section{Extraction of microphytobenthos}

Sediment cores were collected by scuba divers during September 2005, at the Saint Anne site (48 21' 610' $\mathrm{N}, 4^{\circ} 33^{\prime} 000^{\prime}$ 'W), in the Bay of Brest (France). At the site, the tidally controlled water depth varies between ca. 4 and 11 meters, and the median grain size of 
the muddy sediments is $100 \mu \mathrm{m}$. Seawater temperature on the day of sampling was 16.4 $( \pm 0.1){ }^{\circ} \mathrm{C}$.

To obtain enough material to perform the experiment in triplicate and concentrate the microphytobenthos, the surface $(1 \mathrm{~cm})$ of 6 undisturbed cores $(9 \mathrm{~cm}$ diameter $)$ were sectioned and transferred to a beaker containing filtered sea water. Because diatoms are less dense than most mineral grains (Klein and Hurlbut 1985), they may be separated from the sediment by differential settling. Accordingly, the sample suspension was thus left aside to allow particles to settle. After a short period of time (5-10 $\mathrm{min})$, the supernatant with suspended diatoms was transferred to a carboy containing $8 \mathrm{~L}$ of filtered seawater at low DSi concentration, suitable for DSi uptake kinetic experiments.

\section{Determination of silicic acid uptake kinetics}

In order to prevent nitrate and phosphate depletion during the incubation, concentrations in the carboy were increased by adding $\mathrm{NaNO}_{3}$ and $\mathrm{Na}_{2} \mathrm{HPO}_{4}$ to 50 and 1.5 $\mu \mathrm{mol} \mathrm{L}{ }^{-1}$, respectively. Aliquots of the sample suspension were then dispensed into 3 series of 10 polycarbonate bottles $(150 \mathrm{~mL})$. Additional subsamples were set aside for triplicate analysis of the major inorganic nutrients (phosphate, nitrate, and ammonium), biogenic silica (BSi), particulate organic carbon (POC) and nitrogen (PON), chlorophyll $a(\mathrm{Chl} a)$, phaeopigments, cell counts, and species determinations. Increasing amounts of DSi, as sodium metasilicate, were then added to the bottles resulting in 3 series of flasks with DSi concentrations ranging from 0 to $300 \mu \mathrm{mol} \mathrm{L} \mathrm{L}^{-1}$.

After mixing and prior to the addition of the radioisotope ${ }^{32} \mathrm{Si}, 10 \mathrm{~mL}$ of the sample were taken and filtered for DSi determination. The same amount of ${ }^{32} \mathrm{Si}$ labelled- $\mathrm{Si}(\mathrm{OH})_{4}$ (in $\mathrm{Na}_{2} \mathrm{SiO}_{3}$ solution, Los Alamos National Laboratory), was added to each bottle (4.17

Becquerels $\mathrm{mL}^{-1}$ ), corresponding to an increase in DSi concentration of $0.02 \mu \mathrm{mol} \mathrm{L}^{-1}$ at the most. Bottles were then hung in situ on a mooring, just above the sea floor. The 
photosynthetically available radiation (PAR) at that depth was estimated indirectly from surface measurements (MAREL Buoy, Observatoire du Domaine Côtier, IUEM) and light extinction coefficients measured at the site (J. Grall unpubl. data). PAR varied from 100 to $150 \mu \mathrm{mol}$ quanta $\mathrm{m}^{-2} \mathrm{sec}^{-1}$ during the incubation. After a 4 hour period, the bottles were returned to the laboratory and cells were collected immediately by filtration through $0.6 \mu \mathrm{m}$ Nuclepore membranes. Each filter was then rinsed with filtered seawater, and placed in a 20$\mathrm{mL}$ plastic scintillation vial. Hydrofluoric acid ( $2 \mathrm{~mL}$ of $2.9 \mathrm{~N} \mathrm{HF})$ was added to each sample to dissolve the BSi. One hour later, $10 \mathrm{~mL}$ of the scintillation cocktail Ultima Gold XR was added. ${ }^{32} \mathrm{Si}$ incorporation was measured using a scintillation counter, as described by Leynaert et al. (1996). The DSi uptake rate was determined for each sample and normalized to the BSi concentration present at the beginning of the incubation, to calculate the specific uptake rate (V).

\section{Particulate matter analysis}

BSi, POC, PON, Chl $a$, and phaeopigments were determined in triplicate on particulate matter collected by filtration of $100 \mathrm{~mL}$ of sample out of the carboy. BSi analysis was performed using the alkaline digestion method (Ragueneau and Tréguer 1994). Concentrations of Chl $a$ and phaeopigments were estimated using the method of Lorenzen (1966) and a KONTRON fluorometer (Kontron Instruments AG). Material for POC and PON measurements was analyzed in a Thermoelectron elemental analyzer (Flash EA). Samples for phytoplankton cell counts and determination were fixed with Lugol's solution and counted using the method of Utermöhl (1958).

\section{Determination of silicic acid concentration in the sediment}

Sediment cores were taken in triplicate in May and October. Immediately subsequent to sampling, the water at the surface of the sediment was collected for the determination of the 
DSi concentration at the water-sediment interface. The sediment was then vertically sectioned into $0.5 \mathrm{~cm}$ intervals $(0-1 \mathrm{~cm})$, and $1 \mathrm{~cm}$ intervals $(1-3 \mathrm{~cm})$, down to $3 \mathrm{~cm}$. The sectioned mud was then centrifuged (15 minutes - $3500 \mathrm{rpm}$, in a refrigerated centrifuge), and the extracted water was filtered through a $0.2 \mu \mathrm{m}$ Nuclepore filter and analyzed for DSi, using standard colorimetric techniques (Tréguer and Le Corre 1975).

\section{Results}

\section{Characteristics of the sample biomass}

The microscopic examination of the microphytobenthos revealed that when the number of cells per liter is considered, Bacillaria paxilifer was the dominant species (600 cells L $\mathrm{L}^{-1}$ ) along with Amphora sp. and Cylindrotheca closterium. Nitzschia sigma, Pleurosigma cf. angulata and Pleurosigma cf. strigosum were also present at concentrations higher than 100 cells L ${ }^{-1}$ (Fig. 1). However, an estimate of the cells biovolume, from microscopically measured linear dimensions of each species, revealed that Gyrosigma cf. balticum and Pleurosigma cf strigosum, because of their large size $\left(1.8 \times 10^{5} \mu \mathrm{m}^{3}\right.$ and $4.3 \mathrm{x}$ $10^{4} \mu \mathrm{m}^{3}$, respectively), greatly dominated the overall biomass (Fig. 2). As these two species are raphid diatoms, they are principally epipelic, i.e., they live freely and are capable of moving vertically within the upper layers of the sediment, in synchronization with day-night and tidal cycles (Round 1971). Only benthic diatom species were observed in these samples.

Biomass characteristics are reported in Table 1. Detritus and empty frustules were abundant in the sample. However, we found a low phaeopigment content as compared to Chl $a$, and the $\mathrm{C}: \mathrm{Chl} a$ ratio (52) is in the range of ratios reported for microphytobenthos (de Jonge 1980). Together, this information indicates that a great proportion of the material was alive. 
Pore water profiles of DSi are presented in Fig. 3. Both profiles, performed at two different seasons (in spring and at the end of the summer) are very similar. They suggest a steep increase in concentrations until a nutrient maximum is reached, around $150 \mu \mathrm{mol} \mathrm{L}{ }^{-1}$, between 1 and $2 \mathrm{~cm}$ below the interface. DSi concentrations of interstitial waters from the 0 $0.5 \mathrm{~cm}$ layer of the sediment ( 91 and $103 \mu \mathrm{mol} \mathrm{L}-1$ ) were more than one order of magnitude higher than in the overlying water $\left(2.7\right.$ and $\left.8.2 \mu \mathrm{mol} \mathrm{L}^{-1}\right)$ in the two cores sampled.

We note that overall DSi pore water concentrations in October were lower than in May. . However, due to the paucity of data and the high variance in concentration, a seasonal trend can not be determined. Although pore water profiles are from May and October, and the experiments were conducted in September, we feel the range of DSi concentrations in the upper $1 \mathrm{~cm}$ of the sediment column is representative of the concentrations that benthic diatoms encounter during vertical migration.

\section{Kinetics of silicic acid uptake}

Specific uptake rates $\left(\mathrm{V}, \mathrm{h}^{-1}\right)$ are plotted against the ambient DSi concentrations (Fig. 4A). At low concentrations, the data seem to follow a rectangular hyperbola, similar to the Michaelis-Menten equation for enzyme kinetics. However, at high concentrations, the data do not suggest uptake saturation, but rather a linear dependence on the DSi concentrations.

As the kinetic profiles suggest a discontinuity, we calculated a half-saturation constant $\left(\mathrm{K}_{\mathrm{s}}\right)$ and a specific uptake rate $\left(\mathrm{V}_{\max }\right)$ for DSi uptake at low concentrations only. The best fit to the Michaelis-Menten function is obtained when considering the range of data from 0 to $60 \mu \mathrm{mol}$ $\mathrm{L}^{-1}$, which gives a $\mathrm{K}_{\mathrm{s}}$ of $54 \mu \mathrm{mol} \mathrm{L} \mathrm{L}^{-1}$ and a $\mathrm{V}_{\max }$ of $0.096 \mathrm{~h}^{-1}$. As the second part of the curve does not show any sign of saturation at higher concentrations, it has been analysed as a linear component, excluding the Michaelis-Menten portion. Thus, for DSi concentrations above 60 $\mu \mathrm{mol} \mathrm{L}{ }^{-1}$ : 
$\mathrm{V}\left(\mathrm{h}^{-1}\right)=0.0049 * \mathrm{~S}(\mu \mathrm{mol} \mathrm{L}-1)-0.2806 \quad\left(r^{2}=0.88\right)$

Closer examination of the curve (Fig. 4B) shows that the linear term does not overlap with the lower range of data, and thus does not affect the estimate of the Michaelis-Menten kinetics at low concentrations.

\section{Potential experimental artifacts}

Kinetic experiments for DSi uptake are seldom performed in triplicate because of the high cost of the ${ }^{32} \mathrm{Si}$ isotope. The good fit and very low scatter in the data provide great confidence in the results.

We recognize that our experimental conditions are designed to exclude particles. However, the method of microphytobenthos extraction results in the presence of empty frustules as well as some clay contamination of the sample and could lead to experimental artifacts due to passive adsorption of the label, particularly when exposed to enriched DSi concentrations. Nonetheless, previous studies in the Danube estuary have shown, using $\mathrm{HgCl}_{2}$ killed controls, that there is little likelihood of an artefact related to ${ }^{32} \mathrm{Si}$ adsorption in turbid waters (Ragueneau et al. 2002). Moreover, studies on DSi adsorption processes carried out on sediment of similar characteristics (Gehlen and Van Raaphorst 2002) reported a maximal rate of $1250 \mu \mathrm{mol} \mathrm{Si} \mathrm{adsorbed} \mathrm{per} \mathrm{kg} \mathrm{of} \mathrm{dry} \mathrm{sediment} \mathrm{at} \mathrm{DSi} \mathrm{concentrations} \mathrm{of} 250 \mu \mathrm{mol} \mathrm{L}^{-1}$. Considering a maximum of $100 \mathrm{mg}$ of sediment per liter in our sample, we calculate that $0.125 \mu \mathrm{mol} \mathrm{Si} \mathrm{L}{ }^{-1}$ could be adsorbed, i.e., two orders of magnitude lower than the uptake rates measured in the kinetic experiment for the same range of DSi concentrations. Thus, it is very unlikely that the adsorption process, if it occurred, affected the measured uptake rate.

\section{DISCUSSION}

Silicic acid uptake by microphytobenthos: a multiphasic mechanism 
It has long been recognized that DSi uptake by diatoms in the pelagic environment is carrier mediated and tends to conform to Michaelis-Menten hyperbolic saturation function (Paasche 1973). Our results are the first data reporting a half saturation constant and maximum specific uptake rate of DSi for a natural benthic diatom community. The data show that the DSi uptake kinetics follows a hyperbolic pattern at low concentrations only $(<60$ $\left.\mu \mathrm{mol} \mathrm{L}{ }^{-1}\right)$. At higher silicate concentrations, the influence of another mechanism becomes apparent (Fig. 4A).

Although these are the result of a single experiment, they suggest the possibility of multi-phase DSi uptake by benthic diatoms. Indeed, despite extensive studies, there is still no consensus about the number and nature of uptake mechanisms in plants (Nissen 1989). For phytoplankton, Michaelis-Menten type saturable kinetics explain the movement of molecules across the cell membranes. However, in higher plants, two types of transfer have been described: the first (carrier mediated transport plus simple diffusion) involves the contribution of a hyperbolic saturation transfer (with a carrier) plus simple linear diffusion (non-carriermediated). In the second, two different carriers, with different kinetic constants are involved (Chrispeels et al. 1999). Among these different types of nutrient transfer, the transport of DSi for benthic diatoms could be explained by the sequential induction of two uptake systems: a carrier mediated transport following a hyperbolic saturation function at "low" concentrations $\left(<60 \mu \mathrm{mol} \mathrm{L}{ }^{-1}\right)$, and a linear term at higher concentrations, whose nature remains to be defined.

\section{- A hyperbolic saturation transfer at "low" concentrations $\left(<60 \mu \mathrm{mol} \mathrm{L}{ }^{-1}\right)$ suggests exceptionally high $K_{s}$ and $V_{\max }$}

In this study, in the range of concentrations considered to fit reasonably well with Michaelis-Menten saturation functions $\left(0-60 \mu \mathrm{mol} \mathrm{L}^{-1}\right)$, the calculated $\mathrm{K}_{\mathrm{s}}$ is $54( \pm 6) \mu \mathrm{mol} \mathrm{L} \mathrm{L}^{-1}$ 
and $\mathrm{V}_{\max }$ is $0.096( \pm 0.020) \mathrm{h}^{-1}$. As no data are available for benthic diatoms, we can compare our results to values obtained for pelagic diatom assemblages from different environments. Such data were summarized by Claquin et al. (2006) where overall means for $\mathrm{K}_{\mathrm{s}}$ and $\mathrm{V}_{\max }$ were $2.48( \pm 1.93) \mu \mathrm{mol} \mathrm{L}^{-1}$ and $0.026( \pm 0.60) \mathrm{h}^{-1}$, respectively. Our calculated values are thus in the higher range of kinetic data reported for pelagic diatoms.

Particularly, the value of $\mathrm{K}_{\mathrm{s}}$ is at least one order of magnitude above those found in pelagic environments suggesting a very low affinity of the benthic diatom for DSi. In some exceptional situations, extremely high $\mathrm{K}_{\mathrm{s}}$ values also have been reported for natural pelagic diatom communities (Brzezinski et al. 1998; Nelson et al. 2001). However, and as stated by the authors, these values were marked with large uncertainties because the relationship between the specific uptake rate and DSi only poorly fitted the Michaelis-Menten hyperbola.

The $\mathrm{V}_{\max }$ we calculated for benthic diatoms also stands above those typically reported for pelagic communities. It is 3 to 4 times higher than the average reported by Claquin et al. (2006), despite the presence of detrital biogenic silica (empty frustules, shell fragments, dead cells, etc.). This is a recurring problem when studying natural diatom communities (whether pelagic or benthic), because viability is not easily determined. Thus, it is possible that the $\mathrm{V}_{\max }$ for the living diatoms could be even higher than the calculated one.

\section{- The linear component}

The linear term is usually considered to represent passive diffusion in higher plants (Nissen 1989). However, diatoms maintain supersaturated DSi concentrations inside the cell (ranging between 19 to $340 \mathrm{mmol} \mathrm{L}^{-1}$ ) (Binder and Chisholm 1980). This means that if the intracellular free pool of DSi can reach millimolar concentrations, passive diffusion would occur against a concentration gradient. However, the soluble form of Si present in the free pool is still ambiguous. Several studies have suggested the existence of organosilicon 
compounds which form a water-insoluble Si pool and would allow for an inward concentration gradient (Sullivan 1979). This is consistent with Thamatrakoln and Hildebrand's (2008) model for uptake in which they suggest that at high DSi, uptake would not be carrier mediated but would rather occur by diffusion.

Another explanation is active carrier-mediated transport of DSi at high concentrations. Based on the likelihood that any carrier-mediated transport should eventually saturate, what we observed as linear uptake would be only the linear portion of a saturating kinetic curve for a very high $\mathrm{K}_{\mathrm{s}}$ (low affinity) transporter. This is consistent with the fact that different Sitransporters (SIT) may co-exist within individual cells (Hildebrand et al. 1998). Since each transporter has a different affinity or capacity for transport, one mode of regulating the uptake of DSi by the diatoms would be by controlling the amount or location of these different types of SITs. This is also in agreement with results from chemostat studies which indicate that 3 distinct modes of DSi uptake can be distinguished in some diatom species (Conway et al. 1976), depending on the intra and extra cellular Si levels. Del Amo and Brzezinski (1999), in reference to the unusual DSi uptake kinetic of the pelagic diatom P. tricornutum, also suggested the possibility of two different transport systems. Recently, Thamatrakoln and Hildebrand (2007) suggested that SIT activity could be internally controlled by the rate of silica incorporation. This calls into question the relationship between uptake and silica deposition. Further studies should be design to examine the evolution of the efflux to influx ratio as a function of DSi concentrations.

\section{The shape of the kinetic curve and the potential advantages it conveys}

Many benthic diatoms are motile and migrate vertically in the sediment in a close relationship with the diel cycle in subtidal areas (Ní Longphuirt et al. 2006), and the daytime and emersion periods in intertidal zones (Serôdio et al. 1997). In muddy sediments, the range of vertical migrations can reach centimeters (Saburova and Polikarpov 2003). It is in these 
first centimeters of sediment that the gradient concentration of DSi is the steepest. What is crucial is that over a migration cycle, benthic diatoms may experience changes in DSi concentrations from a few micromolar at the sediment-water interface up to more than 100 $\mu \mathrm{mol} \mathrm{L} \mathrm{L}^{-1}$ in the first $\mathrm{cm}$ of sediment (Fig. 3). Other studies have reported concentrations even higher, exceeding $300 \mu \mathrm{mol} \mathrm{L}{ }^{-1}$ in the first cm of sediment (Sundbäck 1991).

This environment differs from the situation encountered by pelagic diatoms. For example, DSi concentrations in the water column overlying the site of sampling in the Bay of Brest range from depletion in spring, to a maximum of about $15 \mu \mathrm{mol} \mathrm{L}^{-1}$ in winter (data from Somlit-Brest, Coastal time-series station). Thus whereas pelagic diatoms experience an order of magnitude difference in the DSi concentration throughout the year, benthic diatoms will undergo variations in DSi concentrations sometimes greater than two order of magnitude, over a 24-hour period, through the process of migration from the sediment surface down to a depth of one $\mathrm{cm}$. Therefore, for benthic diatoms, the variation in concentration is more pronounced, and the frequency at which these variations occur is also much higher.

In such an environment, the multiphasic mechanism for uptake gives benthic diatoms the possibility to take maximum advantage of the high DSi concentration found deeper in the sediment. Consequently, this suggests that microphytobenthos would reliably take up silicic acid from sediment, rather than from the water column because they are much less effective in their ability to collect and transport substrate at low surface silicic acid concentrations. However, we must acknowledge that the uptake experiment was conducted in light and thus did not simulate the conditions where the linear uptake with higher concentrations would be occurring in the field (in the dark and often anoxic subsurface sediment). The direct availability of light is not necessary for DSi uptake as silicon metabolism is not directly connected to photosynthesis (Brzezinski 1992). But the availability of oxygen might be of a concern as energy for silicification is provided by aerobic respiration (Lewin 1955). 
Saburova and Polikarpov (2003) also suggested that diatoms were more likely to assimilate DSi in subsurface sediments. They found a higher percentage of cells in G2 and mitosis stages of the cell cycle below the surface, which are the stages of the cell cycle that are more specifically coupled to the DSi assimilation by diatom species (Claquin and MartinJézéquel 2005). Conversely, others (Sundback 1991; Sigmond and Cahoon, 1997) have shown benthic DSi fluxes to decrease, and even to reverse, during periods of illumination, suggesting the influence of microphytobenthos on DSi is strongest at midday, i.e., when cells are concentrated at the surface of the sediment. Thus, whether diatoms utilize DSi when they are concentrated at the surface during day light, or from sediment pore water, or both, is still unclear but is an interesting area for future research.

This study provides first evidence for multiphasic uptake of DSi by benthic diatoms. We can not rule out that pelagic diatoms subjected to high DSi concentrations would not demonstrate the same transport mechanism. It may call into question the concept of nutrient limitation, as the activation of a second uptake system at high concentrations could lead to unsaturable DSi uptake. However, we are aware of the limitations of the data set and that this is the result of a single experiment. Follow up studies are needed to better understand the physiological ecology of benthic diatoms in relation to the strong gradients in physical or chemical microenvironment in surface sediment. These include further work on the evolution of the efflux to influx ratio in diatoms as a function of DSi concentrations, on how multiphasic uptake of silicic acid (and other nutrients) relates to vertical migration by the diatoms, oxygen and light conditions in the subsurface sediments. 


\section{References}

Binder, B. J., and S. W. Chisholm 1980. Changes in the soluble silicon pool size in the marine diatom Thalassisira weissflogii. Mar Biol Letters 1: 205-212.

Brzezinski, M. A. 1992. Cell-cycle effects of silicic acid uptake and resource competition among diatoms. J. Plank. Res. 14: 1511-1539.

Brzezinski, M. A., T. A. Villareal, and F. Lipschultz 1998. Silica production and the contribution of diatoms to new and primary production in the central North Pacific. Mar. Ecol. Progr. Ser. 167: 89-104.

Cahoon, L. B. 1999. The role of benthic microalgae in neritic ecosystems. Oceanogr. Mar. Biol. Ann. Rev. 37: 47-86.

Chrispeels, M. J., N. M. Crawford, and J. I. Schroeder 1999. Proteins for transport of water and mineral nutrient across the membrane of plant cells. The Plant Cell 11: 661-675.

Claquin, P., A. Leynaert, A. Sferratore, J. Garnier, and O. Ragueneau 2006. Physiological ecology of diatoms along the land-sea continuum, p.18-24. In V. Ittekot, C. Humborg and J. Garnier [eds.], Land-Ocean nutrient fluxes: silica cycle. SCOPE book series, $\mathrm{n}^{\circ}$ 66. Island Press.

Claquin, P., and V. Martin-Jézéquel 2005. Regulation of the Si and C uptake and of the soluble free-silicon pool in a synchronised culture of Cylindrotheca fusiformis (Bacillariophyceae): effects on the Si/C ratio. Mar. Biol. 146: 877-886.

Conley, D. J., C. L. Schelske, and E. F. Stoermer 1993. Modification of the biogeochemical cycle of silica with eutrophication. Mar. Ecol. Progr. Ser. 101: 179-192.

Conway, H. L., P. J. Harrison, and C. O. Davis 1976. Marine diatoms grown in chemostats under silicate or ammonium limitation. II. Transient response of Skeletonema costatum to a single addition of the limiting nutrient. Mar. Biol. 35: 187-199. 
De Jonge, V. N. 1980. Fluctuations in the organic carbon to chlorophyll a ratios for estuarine benthic diatom populations. Mar. Ecol. Progr. Ser. 2: 345-353.

Del Amo, Y., and M. A. Brzezinski 1999. The chemical form of dissolved Si taken up by marine diatoms. J. Phycol. 35: 1162-1170.

Gehlen, M., and W. Van Raaphorst 2002. The role of adsorption-desorption surface reactions in controlling interstitial $\mathrm{Si}(\mathrm{OH})_{4}$ concentrations and enhancing $\mathrm{Si}(\mathrm{OH})_{4}$ turn-over in shallow shelf seas. Cont. Shelf Res. 22: 1529-1547.

Hildebrand, M., K. Dahlin, and B. E. Volcani 1998. Characterization of a silicon transporter gene family in Cylindrotheca fusiformis: sequences, expression analysis, and identification of homologs in other diatoms. Mol. Gen. Genet. 260: 480-486.

Klein, C., and C. S. Hurlbut Jr. 1985. Manual of mineralogy, 20th ed. J. Wiley \& Sons.

Leynaert, A., P. Tréguer, D. M. Nelson, and Y. Del Amo $1996 .{ }^{32} \mathrm{Si}$ as a tracer of biogenicc silica production: Methodological improvements, p. 29-35. In J. Baeyens, F. Dehairs and L. Goyens [eds.], Integrated marine system analysis. Minutes of the first meeting of the European Network for Integrated Marine Systems Analysis. Bruges.Vrije Universiteit Brussel. Laboratorium voor Analytische Chemie.

Lewin, J. C. 1955. Silicon metabolism in diatoms: III. Respiration and silicon uptake in Navicula pelliculosa. J. Gen. Physiol. 39: 1-10.

Lorenzen, C. J. 1966. A method for continuous measurement of in vivo chlorophyll concentration. Deep Sea Res. 13: 223-227.

Mac-Intyre, D. C. G., R. J. Geider, and D. C. Miller 1996. Microphytobenthos: The ecological role of the "secret garden" of unvegetated, shallow-water marine habitats, 1.

Distribution, abundance and primary production. Estuaries 19:186-201. 
Nelson, D. M., M. A. Brzezinski, D. E. Sigmon, and V. M. Franck 2001. A seasonal progression of Si limitation in the pacific sector of the southern ocean. Deep-Sea Res. II 48: $3973-3995$.

N1' Longphuirt, S., A. Leynaert, J. M. Guarini, L. Chauvaud, P. Claquin, O. Herlory, E. Amice, P. Huonnic, and O. Ragueneau 2006. Discovery of microphytobenthos migration in the subtidal zone. Mar. Ecol. Progr. Ser. 328: 143-154.

Nissen, P. 1989. Multiphasic uptake of potassium by corn roots. No linear component. Plant Physiol. 89: 231-237.

Paasche, E. 1973. Silicon and the ecology of marine plankton diatoms. II. Silicate uptake kinetics in five diatom species. Mar. Biol. 19: 262-269.

Ragueneau, O., and P. Tréguer 1994. Determination of biogenic silica in coastal waters: Applicability and limits of the alkaline digestion method. Mar. Chem. 45: 43-51.

Ragueneau O., C. Lancelot, V. Egorov, J. Vervlimmeren, A. Cociasu, G. Déliat, A. Krastev, N. Daoud, V. Rousseau, V. Popovitchev, N. Brion, L. Popa, and G. Cauwet 2002. Biogeochemical transformations of inorganic nutrients in the mixing zone between the Danube river and the northwestern Black Sea. Estuar. Coast. Shelf S. 54: 321-336.

Round, F. E. 1971. Benthic marine diatoms. Oceanogr. Mar. Biol. Ann. Rev. 9: 83-139.

Saburova, M. A., and I. G. Polikarpov 2003. Diatom activity within soft sediments: behavioural and physiological processes. Mar. Ecol. Prog. Ser. 251: 189-207.

Serôdio J., Marques da Silva J., and F. Catarino 1997. Nondestructive tracing of migratory rhythms of intertidal benthic microalgae using in vivo chlorophyll a fluorescence. J. Phycol. 33: 542-55.

Sigmon, D. E., and L. B. Cahoon 1997. Comparative effects of benthic microalgae and phytoplankton on dissolved silica fluxes. Aquat. Microb. Ecol. 13: 275-284. 
Srithongouthai, S., Y.-I. Sonoyama, K. Tada, and S. Montani 2003. The influence of environmental variability on silicate exchange rates between sediment and water in a shallow-water coastal ecosystem, the Seto Inland Sea, Japan. Mar. Poll. Bull. 47: 10-17.

Sullivan C. W. 1979. Diatom mineralization of silicic acid. IV. Kinetics of soluble Si pool formation in exponentially growing and synchronized Navicula pelliculosa. J. Phycol. 15: $210-216$

Sundbäck, K. 1991. Influence of sublittoral microphytobenthos on the oxygen and nutrient flux between sediment and water: A laboratory continuous-flow study. Mar. Ecol. Progr. Ser. 74: 263-279.

Thamatrakoln, K., and M. Hildebrand 2007. Analysis of Thalassiosira pseudonana silicon transporters indicates distinct regulatory levels and transport activity through the cell cycle. Eukariotic Cell 6: 271-279.

Thamatrakoln, K., and M. Hildebrand 2008. Silicon uptake in diatoms revisited: a model for saturable and nonsaturable uptake kinetics and the role of silicon transporters. Plant Physiol. 146: 1397-1407.

Tréguer, P., and P. Le Corre 1975. Manuel d'analyse des sels nutritifs dans l'eau de mer: utilisation de 1'auto-analyseur Technicon II. $2^{\text {nd }}$ edition, UBO.

Uthermohl, H. 1958. Zur Vervollkommnung der quant itativen Phytoplankton-Methodik. Mitteilungen Internationale Verein Limnologie, Stuttgard. 9: 1-38.

Ziervogel, K., and S. Forster 2006. Do benthic diatoms influence erosion thresholds of coastal subtidal sediments? J. Sea Res. 55:43- 53. 


\section{Tables}

Table 1: Biomass characteristics of the microphytobenthos sample

\begin{tabular}{cccccc}
\hline & $\begin{array}{c}\text { POC } \\
\left(\mu \mathrm{mol} \mathrm{L}^{-1}\right)\end{array}$ & $\begin{array}{c}\text { PON } \\
\left(\mu \mathrm{mol} \mathrm{L}^{-1}\right)\end{array}$ & $\begin{array}{c}\text { BSi } \\
\left(\mu \mathrm{mol} \mathrm{L}^{-1}\right)\end{array}$ & $\begin{array}{c}\text { Chlorophyll } a \\
\left(\mu \mathrm{g} \mathrm{L}^{-1}\right)\end{array}$ & $\begin{array}{c}\text { Phaeopigments } \\
\left(\mu \mathrm{g} \mathrm{L}^{-1}\right)\end{array}$ \\
\hline concentration & 15.14 & 0.96 & 2.64 & 3.49 & 0.41 \\
$\mathrm{SD}(n=3)$ & 0.4 & 0.10 & 0.23 & 0.89 & 0.60 \\
\hline
\end{tabular}




\section{Figure captions}

Figure 1: (A) Gyrosigma cf. balticum and (B) Pleurosigma cf. strigosum greatly dominated the overall biomass because of their large size $\left(1.8 \times 10^{5} \mu \mathrm{m}^{3}\right.$ and $4.3 \times 10^{4} \mu \mathrm{m}^{3}$, respectively).

Figure 2: Cell abundance $\left(\right.$ cells $\left.\mathrm{L}^{-1}\right)$ and volume $\left(\mu \mathrm{m}^{3} \mathrm{~L}^{-1}\right)$ of the main species present in the microphytobenthos extracted from the sediment.

Figure 3: Pore water profiles of silicic acid.

Figure 4: (A) Specific silicic acid uptake rates $\left(\mathrm{V}, \mathrm{h}^{-1}\right)$ plotted against the ambient silicic acid concentration $\left.(\mu \mathrm{mol} \mathrm{L})^{-1}\right)$. At low concentrations $\left(0-60 \mu \mathrm{mol} \mathrm{L}^{-1}\right)$, the data are fitted to the Michaelis-Menten equation for enzyme kinetics, and to a linear function at higher concentrations. (B) Details of the data analysis showing that the linear part of the curve does not overlap with the lower range of data. 

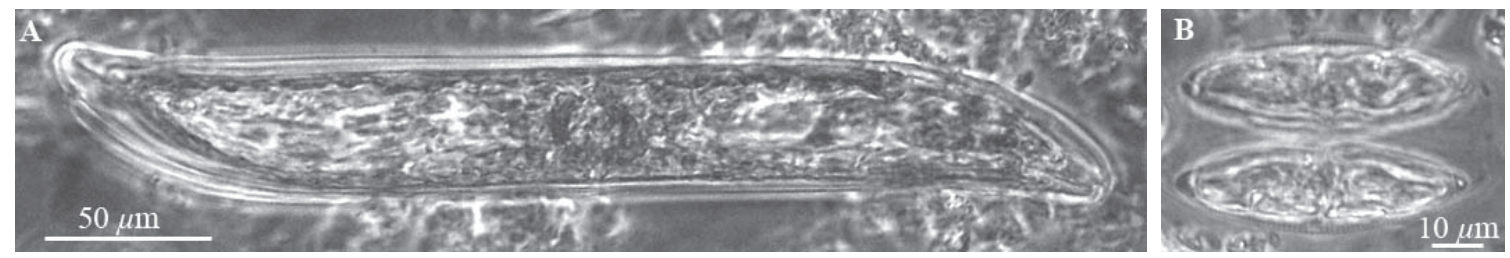

Fig. 1 


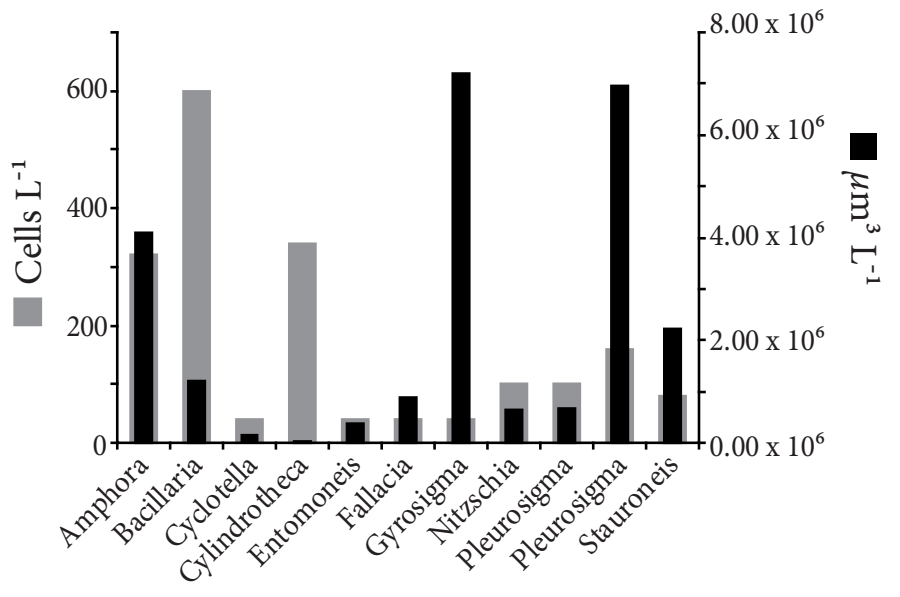

Fig. 2 


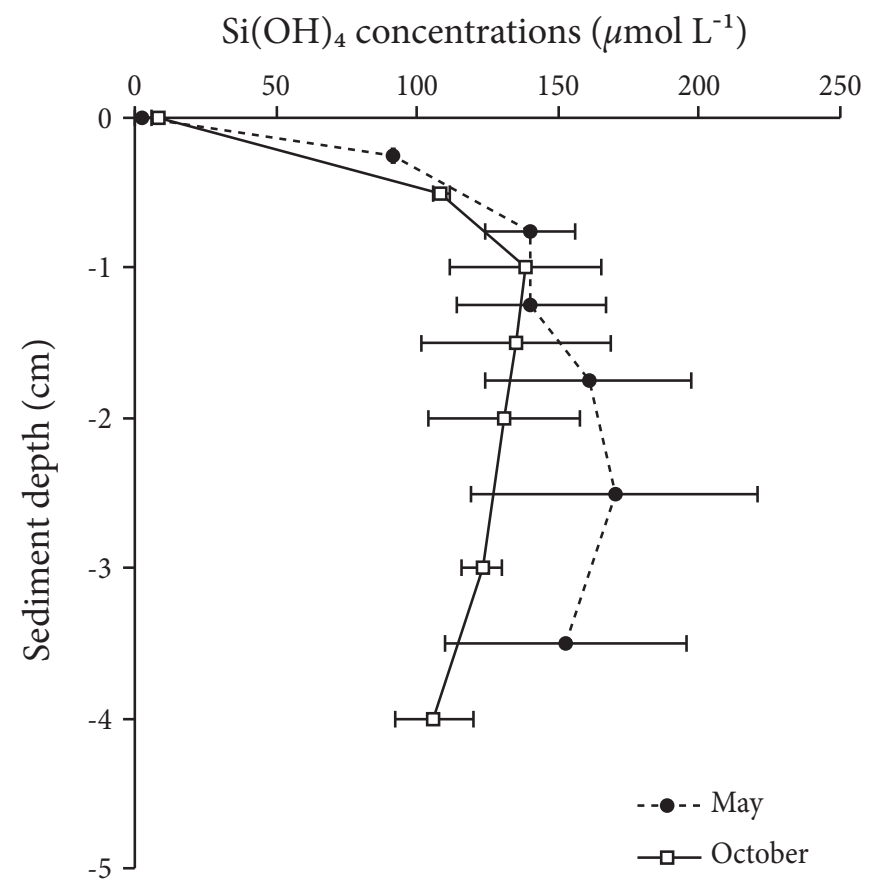

Fig. 3 

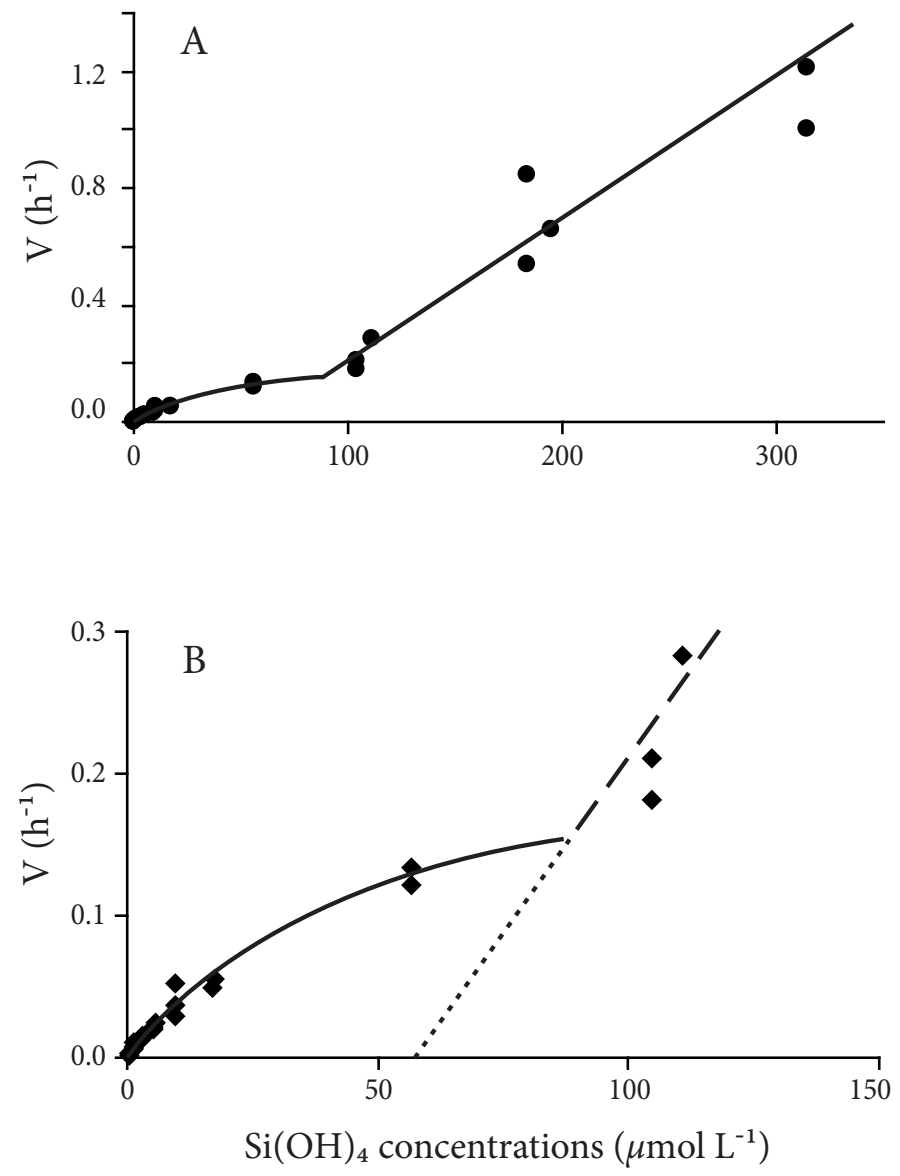

Fig. 4 